\title{
Gastón Baquero, poeta hermético.
}

\author{
Ricardo Arturo Ríos Torres ${ }^{1, *}$ \\ ${ }^{1}$ Catedrático, escritor y promotor cultural. Profesor jubilado de la Universidad Católica Santa María la \\ Antigua (USMA), Panamá, República de Panamá. \\ ${ }^{*}$ Autor para correspondencia. Email: rriost@,hotmail.com
}

Recibido: 1 de diciembre de 2015

Aceptado: 9 de diciembre de 2015

\begin{abstract}
The following work synthetizes information extracted from the book "La Vsibilidad de lo Oculto", by the essay writer Humberto López Cruz, where the life and the transcendence of the works by the Cuban poet Gastón Baquero are exposed. These aspects are analyzed through the perspective of diverse Latin American literature scholars, mostly foreigners. The author adds the critical vision of several local authors.
\end{abstract}

Keywords: Cuban poetry; Cuban poetry of the exile; Latin American poetry; Literature.

\section{Resumen}

El presente trabajo sintetiza información extractada del libro, la Visibilidad de lo Oculto, del ensayista Humberto López Cruz, en donde se expone sobre la vida y la trascendencia de la obra del desaparecido poeta cubano Gastón Baquero, aspectos analizados desde la perspectiva de diversos estudiosos de las letras latinoamericanas, extranjeros. El autor añade la visión crítica de algunos autores locales.

Palabras clave: Poesía cubana; Poesía cubana del exilio; Poesía latinoamericana; Literatura.

A Luis Pulido Ritter

\section{Introducción}

Humberto López Cruz, de la University Central Florida en Orlando, logra un compendio de excepción al editar La visibilidad de lo oculto una aproximación académica desde múltiples perspectivas de un hombre de letras de la América criolla: José Gastón Eduardo Baquero y Díaz (1918-1997) nacido en el oriente cubano es poeta, ensayista, traductor, crítico literario, editor, periodista y un humanista del siglo XX.

Gastón era pobre, mulato, homosexual, provinciano, simpático, corpulento, cordial, hombre ilustre y conservador, del refinado bon vivant, gris y modesto, con la gracia de un humor natural, fue un hombre asequible y risueño, gustaba de los raros y marginados. Se exilió de Cuba en 1959. 
La visibilidad de lo oculto reúne nueve ensayos con pensamiento crítico. Los estudiosos realizan un abordaje sin complacencias ni concesiones, de un intelectual que se expresó con autenticidad quijotesca; cada estudio incluye la bibliografía consultada.

El poeta destaca por su vasta cultura y el marcado interés hacia la polémica. El promotor cultural con un profundo sentido del decoro era ajeno a los fastos de la celebridad, pretendía hacerse invisible, era público su tácito aborrecimiento por el protagonismo, era un hombre impersonal. José Gastón Eduardo Baquero y Díaz era un poeta vestido por la luz, eso lo hace siempre actual.

Opinión de Pío E. Serrano. Editor y escritor.

El hombre no es, deviene. Nada puede secar el árbol de la poesía.

Gastón

Gastón es un nombre proscrito en las letras cubanas, el silencio hostil de los comisarios del régimen obliga a rescatar al secuestrado; es un hombre espejo empeñado en ocultar su talento en el juego de identidades. Aboga por una memoria civilizadora mediante la invención libre de ataduras conceptuales.

Poemas invisibles (1991) expresa con señorial escepticismo las íntimas obsesiones, reacio al mundo de las vanidades reafirma lo mutable del ser ontológico, somos muchas cosas a la vez, tenemos una identidad múltiple. El bardo es irreverente ante todo, lo vital es mantenerse plenamente libre. La eticidad existencial va unida a su auténtico fervor hacia lo cubano.

Pío Serrano valora al poeta ausente como una voz auténticamente americana con resonancia universal, sus poemas inaugurales al estilo de Rimbaud y Eliot tienen el élan de lo fundacional. La lucidez expresiva y el esplendor sustentan la ansiedad por la literatura.

El poeta - niño es un ser que nace para desocultar, para dialogar con las estrellas; hay unidad intuicional en toda las fabulaciones que inventa. El innominado teje con palabras un pedalear con la nada, el discurso poético redime, la estética es de horizontes ilimitados, el propósito es un coloquio permanente.

Opinión de Jesús J. Barquet. New Mexico State University.

La poesía es el fundamento que sostiene la bistoria. Heidegger Publicar es como arrojar al mar botellas con mensajes sin destinatario.

Gastón

Los criterios ideoestéticos del hispanista cubano se encarnan en el intenso trabajo literario y editorial, allí están las traducciones poéticas de los inmortales vates del universo lírico. Revistas como Espuela de Plata, Clavileño, Poeta, Nadie Parecía, Verbum, Tendencias, Cuaderno mensual de poesía y su apoyo fundacional a Origenes demuestra su amistad intelectual con la diversidad creativa de un mundo laberíntico como 
Invest. pens. crit.

Vol. 3, No. 3, septiembre-diciembre 2015

pp. 74-79

lo es el mundo de las letras; su afán es rescatar los signos de una identidad en crisis, así como el acervo común de la humanidad.

Memorial de un testigo concreta la sed de universalidad, Gastón aprecia que lo nacional no riñe con lo universal, que es imperativo asumir lo valioso de los otros y sobre todo las arcaicas esencias; insiste en la internación, la vida hacia adentro, y se empeña en la revalorización de la historia y la cultura hacia una cohesión profunda de actitudes y principios. Y lo poetiza: aquí estamos, este es mi testimonio, es el Baquero -crítico en la búsqueda del corazón atormentado de la patria.

Opinión de María Lucía Puppo. Universidad Católica de Argentina

Su pasado persigue un pasado más puro que los cielos.

Gastón

El diálogo entre imagen y palabra, la cultura visual ocupan el interés de un niño misterioso en metamorfosis permanente, así afirma en el Silente compañero: estoy solo, soy una isla. El poliformismo lo enriquece con imágenes sensoriales y metáforas siempre en interacción; todos marchamos entre la sombra y la luz:

La meditación filosófica y teológica florece en los poemas: comprendo que todo está ya escrito, y borrado, y vuelto a escribir. La duda existencial tiene en él múltiples resonancias: somos un sueño de Dios. El nihilismo de Baquero es evidente, oscila entre la duda y la fe.

Opinión de Carlos Cuadra. Stephen F. Austin State University

Ese señor que lleva mariposas en los hombros, solo quiere descubrir el sendero que lo lleve a hundirse para siempre en las estrellas.

Gastón

El monólogo dramático es uno de los recursos líricos altamente elaborados por Baquero. Su voz poética no es un rostro, sino una máscara, un testimonio del misterio de la existencia, de la imposibilidad de comprender el universo o el papel del yo. El yo es fluido y ambiguo, refleja la cautela metafísica. La libertad se alcanza a través de paradojas; como Borges considera que un hombre equivale a otros hombres, cuando Juan Sebastián comenzó a escribir La Cantata del café, yo estaba alli... Yo fui un soldado que durmió en el lecho de Cleopatra... Yo be escuchado la música secreta que sale de tu corazón (a Nefertiti), la conexión con el otro es posible.

El yo de Gastón es proteico, en una multiplicidad de facetas cambiantes el yo es muchos otros con la capacidad de transmutarse sin límites. La alquimia del verbo hace del ser humano muchos seres al mismo tiempo. El ser es dialéctico, cibernético. El yo emerge en paisajes oníricos. La pluralidad de voces interiores nos conduce a un nosotros que incluye al lector. 
La intuición poética supera a la razón, llega hasta la comprensión íntima del mundo. El ethos del poeta ilumina todas las situaciones humanas, el conocimiento poético es efímero, debemos disfrutarlo como si fuese eterno. Gastón igual que José Martí, aprendió a vivir con la cruz sobre los hombros.

Opinión de Manuel Fuentes Vásquez. Universitat Rovira i Virgili. Tarragona, España.

\section{Aprender a leer requiere treinta años.} Aprender a sentir toda la vida.

Gastón

Nadie dijo que era fácil caminar sobre sueños.

Lourdes Casal

Sueños y ensueños sustentan la poética del aedo desterrado. Baquero dramatiza un hecho real y transmuta la realidad humana. El vaivén del oleaje de la memoria construye y deshace lo vivido, lo soñado y lo imaginado. La búsqueda de la verdad en la mentira o de la mentira en la verdad es constante. Gastón siente que la poesía hermana el pensar y el sentir.

Opinión de Ricardo Baixeras Borrel. Colegio Jesuitas de Sarría, Barcelona.

El que escribe no sabe El que lee tampoco sabe.

Gastón

Baixeras reconoce las voces antiguas que encarna Gastón, la fe inquebrantable del rapsoda que habla con el alma, es un sujeto contradictorio y escindido, siempre irreverente y transgresor, coloquial y erudito, sufre un desdoblamiento en cada estallido de la lírica, es un ente en constante ebullición; lo distingue la llaneza del estilo y siempre estar en contra rema.

El silente en su catarsis escribe en la arena para develar lo sustancial y mostrar una perspectiva nueva, es la manera de soñar en el umbral de lo inédito. Gastón es un ser reflexivo que usa la contra-memoria para alcanzar la libertad plena.

El poeta ciego, el poeta niño es una metáfora de su errancia ontológica. Yo soy un inocente, es el ser primigenio que juega con el tiempo, es la agudeza interrogatoria que intenta descifrar los sentidos imposibles. La dialéctica nos ayuda a comprender lo impredecible y lo delirante, la raíz del recuerdo.

Opinión de Erasto Antonio Espino Barahona. Universidad Católica Santa María La Antigua, Panamá

Tiene el alma del poeta. Con la voz de un niño tiembla.

José Martí 
Invest. pens. crit.

Vol. 3, No. 3, septiembre-diciembre 2015

pp. $74-79$

El poeta debe ser libre.

Holderlin

La voz excepcional del poeta isleño es fruto de una arrolladora imaginación, crea otra realidad siempre inefable. Palabras escritas en la arena por un inocente (1941) subjetividad que problematiza una escritura con entes contrarios es un desafío a su creatividad. El hablante y su escritura juegan en una dimensión desconocida, el poema es una parábola entre un ser infantil, marginado, nunca escuchado con un discurso que la historia ignora. Un grito en oídos sordos. Un drama existencial en un oficio irrenunciable, sin que se canse nunca.

Yo no sé escribir y soy un inocente.

Nunca he sabido para qué sirve la escritura.

Ignoran que soy solamente un niño, un fragmento de polvo llevado y traído

por el peso de su corazón.

Voy de alucinación en alucinación, soy tan solo el niño olvidado

durmiéndose en la arena.

El poeta hermético dialoga a partir de los propios versos que escribe. El lector tiene acceso privilegiado cuando se interna en su textura y abdica de lo racional e intuye las coordenadas de una geografía personal, que está allí para ser explorada. Gastón, el poeta romántico, es subversivo, anticonvencional, rompe paradigmas. La identidad raizal es la de un navegante ciego en busca de su morada entre las estrellas.

Gastón supera los márgenes establecidos se rebela contra toda norma. Lucha por ser y escribir, sus poemas son un juego dramático de voces. Las palabras las lee en los cielos a sabiendas de que en Dios tienen sentido. Y sabe que Dios vendrá a recogerle un día detrás del laberinto. La poética de Gastón es sólida y articulada, tiene coherencia conceptual. El iluminado se hace existencialmente con su escritura.

Opinión de María del Carmen Caña Jiménez. Virginia Tech

$$
\begin{array}{r}
\text { Indios, europeos y africanos } \\
\text { obligados a convivir } \\
\text { pasaron a ser americanos. } \\
\text { Gastón }
\end{array}
$$

Gastón evidencia una constante correlación de grupos humanos con el color de un sentimiento utópico. La realidad es una parodia, el tejido social del latinoamericano está en permanente colisión, no hay tal Edad Dorada de sociedades ideales. La heterogeneidad se pierde en un dualismo múltiple de identidades en conflicto. El mestizaje es una imposición del vencedor, los rebeldes eran implacablemente barridos por el poder imperial con el régimen de castas. Los aborígenes y negros pasaron a ser invisibles. 
María del Carmen al problematizar el fundamento conceptual de Baquero en torno a Hispanoamérica y España, confronta las incoherencias y contradicciones de postulados que para ella resultan incongruentes por la actitud esquizofrénica de amar por igual a dos tierras.

Opinión de Santiago Juan Navarro. Florida International University

Hay racismo porque hay miedo. Gastón

El ensayista cubano en las reflexiones sobre la Hispanidad mitifica y desmitifica sobre el conjunto de lecturas e investigaciones. La otredad de un pasado controversial choca con la autarquía filofacista de un régimen conservador y reaccionario encarnado por Francisco Franco.

El mito de la Hispanidad defiende una "teología mágica de la historia”, es la utopía regresiva, un modelo autoritario con una visión retrógrada del nacionalismo mesiánico propio del franquismo. Desde la otra orilla, voces disidentes consideran que son fantasías religiosas e imperiales con hedor a sepulcro, de nostalgia monacal.

Santiago Juan comenta la ferviente hispanofilia de Gastón Baquero como una alternativa de las tendencias unionistas producto de un encuentro multiétnico y pluricultural. La Hispanidad es la nueva ficción sobre el mestizaje en el Nuevo Mundo, es excluyente y una curiosa filantropía de los que defendían las encomiendas, la esclavitud y el sometimiento de los vencidos.

Gastón Baquero, ajeno a las ambivalencias y la evocación idealizada, lejos del vaivén de luces y sombras abogó por la integridad psicológica, étnica, histórica y cultural de una Patria libre, justa y feliz, una Patria de todos. El racismo es la supervivencia del hombre primitivo, solo se supera con una regeneración personal y colectiva.

La independencia no acabó con el racismo ni produjo un cambio sustancial en las estructuras sociales y económicas, se incrementaron las desigualdades y las injusticias del colonialismo. El indio y el negro continuaron siendo los siervos de la gleba.

El poeta confía que de esta bervidura ha de salir un sistema donde queden abolidos los privilegios de raza y casta. Consuelo Triviño en Gastón Baquero en el caldero de América subraya que el proceso de humanización puede concretar la utopía del cubano y cita a Habermas cuando intuye que "el hombre posible" se encuentra en Latinoamérica.

La visibilidad de lo oculto editada por Humberto López Cruz adjunta una bibliografía exhaustiva referente a Gastón Baquero con libros, artículos, ensayos, entrevistas.

\section{Referencia}

López Cruz, H. (2015). La visibilidad de lo oculto. Madrid, España: Editorial Hispano Cubana, 2015. 